\title{
Different scoring systems in acute alcoholic pancreatitis: which one to follow? An ongoing dilemma
}

\author{
Deepak JAIN ${ }^{1}$, Gourab BHADURI ${ }^{1}$ and Promil JAIN ${ }^{2}$
}

Received 11/3/2019 Accepted 19/7/2019

\begin{abstract}
Background - Acute pancreatitis is a common disorder in medical practice. In recent times, management has changed drastically with majority of decisions like intravenous antibiotics, negative suction with Ryle's tube and surgical interventions like necrosectomy etc based on severity of the disease. There are different scores in use to assess severity of disease but the relative efficacy has remained a debatable subject. Objective - The present study was thus done to investigate the predictive accuracy of different scoring systems in acute pancreatitis. Methods - Fifty patients of acute pancreatitis admitted in medicine ward of Pt. B.D. Sharma PGIMS, Rohtak, India, were taken for study after fulfilling eligibility criteria. These patients were investigated at admission and followed up prospectively. The severity of pancreatitis was classified for each of these patients as per Revised Atlanta System of Classification. Commonly used scoring systems pertaining to acute pancreatitis, viz, BISAP, Ranson, APACHE II and modified computed tomography severity index (CTSI) were calculated. Subsequently these scores were then correlated with severity, presence of organ failure, occurrence of local complications and final outcome of the patients. Results - Out of 50 patients, etiology was chronic alcohol intake in all but one with idiopathic pancreatitis. The mean age of the study population was $42.06 \pm 13.27$ years. $32 \%$ of these patients had pancreatic necrosis, $40 \%$ had peripancreatic collections. $56 \%$ of them had mild acute pancreatitis, $24 \%$ had moderately severe acute pancreatitis, while $20 \%$ had severe acute pancreatitis. APACHE II had the highest accuracy in predicting severity, organ failure and fatal outcomes. As far as these parameters were concerned, the negative predictive values of BISAP score were also considerable. Modified CTSI score was accurate in predicting local complications but had limited accuracy in other predictions. Conclusion - APACHE II emerged as most reliable scoring system followed by BISAP and Ranson in management of the patients with acute pancreatitis. But in constraints of time and resources, even BISAP score with its significant negative predictive values served as a valuable tool for assessing and managing these patients.
\end{abstract}

HEADINGS - Alcoholic pancreatitis, classification. Alcohol drinking. Adult. Data accuracy.

\section{INTRODUCTION}

Acute pancreatitis is a commonly encountered clinical problem in day to day practice, often posing a challenge for the treating physician. It is a protean disease, with variable clinical presentation, ranging from mild abdominal pain to death ${ }^{(1)}$.

Acute pancreatitis has an incidence of around $2.29 \% \%^{(2)}$. Although most of these patients recover without any sequelae, about $10 \%$ to $20 \%$ of patients may have a severe attack of acute pancreatitis, even with a mortality of $20 \%{ }^{(3,4)}$. Worldwide, gall stones are commonly known to precipitate acute pancreatitis, however studies in India reflect alcohol intake as a more common etiology ${ }^{(5,6)}$. As alcohol intake is a frequent menace precipitating acute pancreatitis, severity of acute pancreatitis must be pre-assessed and physician must be ready to face any outcome.

Several scoring systems were devised to assess the severity and prognosis of acute pancreatitis. The earliest of all is the Ranson scoring system introduced by Ranson and his colleagues in 1974, based on 11 parameters obtained at the time of admission and 48 hours later ${ }^{(7)}$. Acute Physiology And Chronic Health Evaluation (APACHE) II , addressing severity in terms of patient's age, previ- ous health status and 12 routine physiologic parameters, was the next to come in $1989^{(8)}$. Using imaging characteristics, Balthazar and his colleagues introduced CT severity index in 1990 that correlated the CT findings with patient's outcome ${ }^{(9)}$. Most recently introduced simplified scoring system is the Bedside Index of Severity in Acute Pancreatitis (BISAP) score based on five parameters, viz, blood urea nitrogen, impaired mental state, systemic inflammatory response syndrome, age and pleural effusion ${ }^{(10)}$. Severity of pancreatitis is classified by the Revised Atlanta System (2012). It incorporated a newer term 'moderately severe acute pancreatitis considering the local complications like necrosis and pseudocyst ${ }^{(11)}$.

There are a number of other scoring systems that are scarcely used these days, but deserve mention. Harmless acute pancreatitis score (HAPS) is one such score ranging from 0 to 3 based on presence of the following parameters: absence of rebound abdominal tenderness; haematocrit $<43 \%$ for males and $<39.6 \%$ for females; serum creatinine $<2 \mathrm{mg}^{0}{ }^{(12)}$. Determinant based classification (DBC) of acute pancreatitis grades pancreatitis into mild, moderate, severe and critical depending upon presence of sterile or infected pancreatic necrosis and transient or persistent organ failure ${ }^{(13)}$. Japanese severity score offers a composite evaluation by including

${ }^{1}$ Pt B D Sharma University of Health Sciences Rohtak, Department of Medicine, Haryana, India. ${ }^{2}$ Pt B D Sharma University of Health Sciences Rohtak, Department of Pathology, Haryana, India. Correspondence: Deepak Jain. E-mail: jaindeepakdr@gmail.com 
age, vital parameters, biochemical parameters and also CT imaging of pancreas. There are only limited studies with these scores and clinicians are hardly well versed with these ${ }^{(14)}$.

Each of these scores have their own merits and limitations, there is always a dilemma regarding use of a particular score in clinical practice. Since, there are only a few studies comparing these scores, this study was aimed to assess and compare the predictive values of these different scoring systems.

\section{METHODS}

The study was conducted on fifty adult patients of acute alcoholic pancreatitis admitted in high dependency unit of Medicine ward at Pt. B. D. Sharma PGIMS, Rohtak. Patients presenting with symptoms suggestive of acute pancreatitis with history of long term alcohol intake were investigated with serum amylase, serum lipase, other biochemical parameters and ultrasonography. Diagnosis was made on the basis of two of the following three criteria's: i) abdominal pain radiating to back consistent with acute pancreatitis ii) elevated serum amylase and lipase to more than three times the upper limit of normal range iii) characteristic findings on ultrasonography like decreased echogenicity of pancreatic parenchyma, surface irregularity and volume increase quantified by pancreatic body exceeding $2.4 \mathrm{~cm}$ in diameter. Patients having underlying neoplasm of pancreas or gall stones or any evidence of chronic pancreatitis like dilation of main pancreatic duct or chain of lake appearance on ultrasonography were excluded from the study. The eligible patients were enrolled and made to undergo routine blood investigations like complete hemogram, hematocrit, renal function test, liver function test, arterial blood gas analysis and serum electrolytes. Demographic characteristics along with vitals were recorded at the very onset. CECT abdomen was done after 72 hours of symptom onset. To eliminate possible confounding factor, all these patients were kept in High Dependency Unit. Vitals, urine output, abdominal girth, bowel sound and electrocardiogram were monitored on regular basis. The patients were then prospectively followed up. BISAP, Ranson, APACHE II and modified computed tomography severity index (CTSI) scores were computed for each of these patients. The following cut-offs were chosen for analysis of morbidity and mortality: BISAP $\geq 2$, APACHE $\geq 8$, Ranson $\geq 3$ and modified CTSI $>4$. These were correlated with presence of organ failure, local complications like peri-pancreatic necrosis and peri-pancreatic collections, severity of acute pancreatitis and final outcome of the patient. Data was analyzed using SPSS version 20.0 software. Organ failure was identified based on Modified Marshall Score (TABLE 1) ${ }^{(15)}$. The severity of acute pancreatitis was graded as per Revised Atlanta System of Classification (2012) $(\text { TABLE 2) })^{(16)}$.
TABLE 2. Revised Atlanta System of Classification of Acute Pancreatitis (2012).

\begin{tabular}{ll}
\hline $\begin{array}{l}\text { Mild acute } \\
\text { pancreatitis }\end{array}$ & $\begin{array}{l}\text { No organ failure. } \\
\text { No local or systemic complications }\end{array}$ \\
$\begin{array}{l}\text { Moderately severe } \\
\text { acute pancreatitis } \\
\text { or local complications like pancreatic necrosis, } \\
\text { peripancreatic collections, pleural effusion }\end{array}$ \\
$\begin{array}{l}\text { Severe acute } \\
\text { pancreatitis }\end{array}$ & Persistent organ failure (persists for $>48$ hours) \\
\hline
\end{tabular}

\section{RESULTS}

Total fifty patients were included in study. The mean age of the study group was $42.06 \pm 13.27$ years. All of these patients were males and had history of chronic alcohol intake. None of these patients had hypertriglyceridemia, hypercalcemia or history of any long term medications like anti-retroviral therapy, analgesics and immunosuppressive drugs known to cause acute pancreatitis. 28 patients belonged to $20-45$ years age group, 21 patients were above 45 years and only one patient was less than 20 years of age. Out of total 50 patients 39 patients survived, while $11(22 \%)$ patients succumbed to the complications. Local complications in form of either necrosis or peri pancreatic collections were present in $16(32 \%) .26 \%$ of the patients had organ failure. $54 \%$ had mild acute pancreatitis, $22 \%$ had moderately severe pancreatitis and $24 \%$ had severe acute pancreatitis. $32 \%$ patients had BISAP $\geq 2$, Ranson $\geq 3$ and modified CTSI $>4$, whereas $24 \%$ patients had APACHE II score $\geq 8$.

It was evident that APACHE II had been most accurate in predicting the presence of organ failure (TABLE 3.A and FIGURE 1.A). The accuracy, sensitivity, specificity and NPV had been highest for modified CTSI in regard to local complications (TABLE 3.B and FIGURE 1.B). The area under curve and accuracy had been highest for APACHE II, followed by BISAP and Ranson, in predicting the severity of acute pancreatitis. It had been least for modified CTSI (TABLE 3.C and FIGURE 1.C). APACHE II followed by BISAP had the highest accuracy in predicting fatal outcome, while modified CTSI had the least accuracy. (TABLE 4 and FIGURE 2). Each of these scoring systems have got significant negative predictive value varying from $85 \%-97 \%$ in all the aforesaid discussed aspects. BISAP score and APACHE II score even had $100 \%$ NPV in predicting outcome. Thus, lower BISAP and APACHE II scores were significant to negate any adverse consequences in the patients.

\section{DISCUSSION}

Acute pancreatitis is a common disease with variable severity. Mild forms usually resolve without any consequences, whereas

TABLE 1. Modified Marshall score.

\begin{tabular}{|c|c|c|c|c|c|}
\hline \multirow{2}{*}{ Organ system } & \multicolumn{5}{|c|}{ Score } \\
\hline & 0 & 1 & 2 & 3 & 4 \\
\hline Respiratory (Pa02/Fio2) $\mathrm{mm} \mathrm{Hg}$ & $>400$ & $301-400$ & $201-300$ & $101-200$ & $<100$ \\
\hline Renal (serum creatinine) & $<1.4 \mathrm{mg} \%$ & $1.4-1.8 \mathrm{mg} \%$ & $1.9-3.6 \mathrm{mg} \%$ & $3.6-4.9 \mathrm{mg} \%$ & $>4.9 \mathrm{mg} \%$ \\
\hline Systolic blood pressure & $>90 \mathrm{~mm} \mathrm{Hg}$ & $\begin{array}{c}<90 \mathrm{~mm} \mathrm{Hg} \text {, fluid } \\
\text { responsive }\end{array}$ & $\begin{array}{l}<90 \mathrm{~mm} \mathrm{Hg} \text {, not } \\
\text { fluid responsive }\end{array}$ & $\begin{array}{c}<90 \mathrm{~mm} \mathrm{Hg}, \\
\mathrm{pH}<7.3\end{array}$ & $\begin{array}{c}<90 \mathrm{~mm} \mathrm{Hg} \\
\mathrm{pH}<7.2\end{array}$ \\
\hline
\end{tabular}

A score of 2 or more in any system defines organ failure. Organ failure more than 48 hrs is termed persistent organ failure and otherwise transient. 
TABLE 3. A) Comparison of various scoring systems in prediction of organ failure. B) Comparison of various scoring systems in prediction of local complications. C) Comparison of various scoring systems in evaluation of severity.

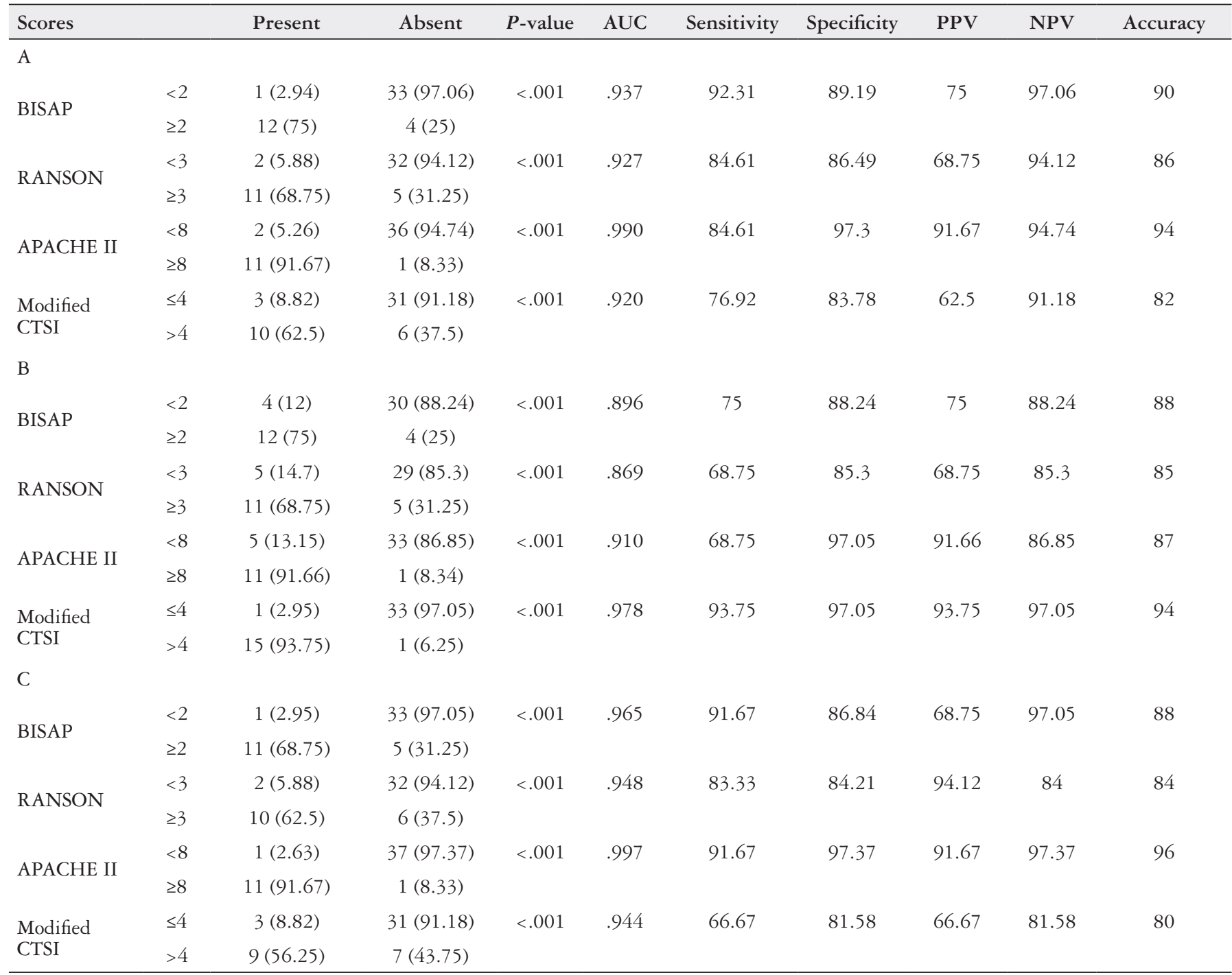

AUC: area under the ROC curve; PPV: positive predicative values; NPV: negative predicative values; BISAP: Bedside Index of Severity in Acute Pancreatitis; APACHE: Acute Physiology And Chronic Health Evaluation.

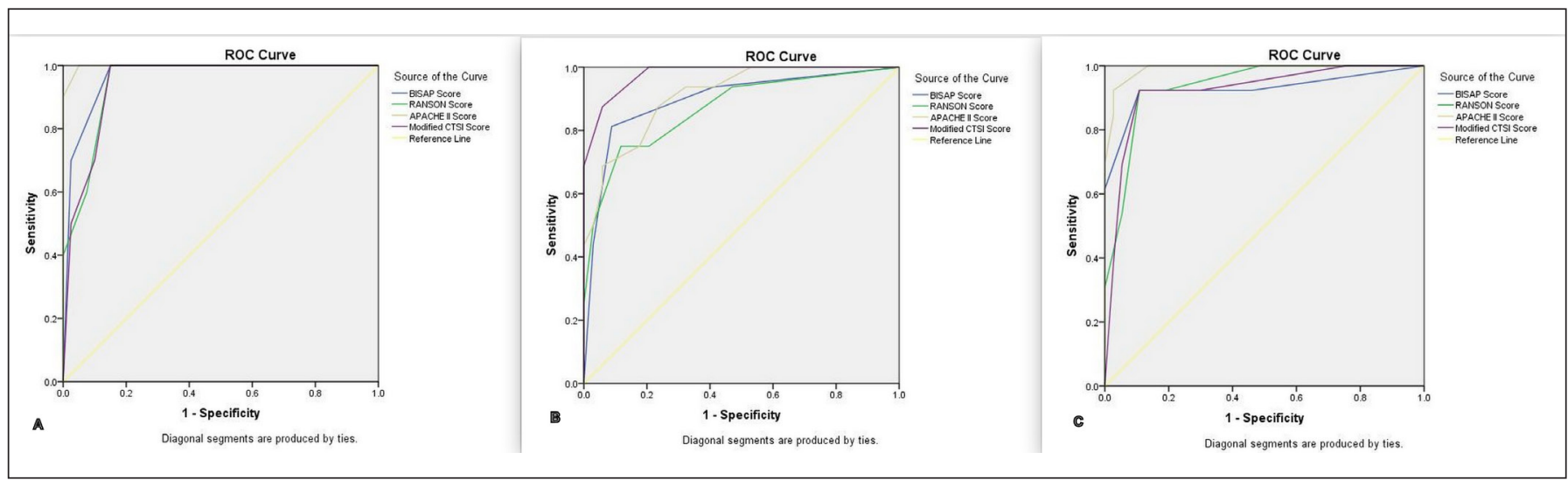

FIGURE 1. A) Comparison of various scoring systems in prediction of organ failure. B) Comparison of various scoring systems in prediction of local complications. C) Comparison of various scoring systems in evaluation of severity. 


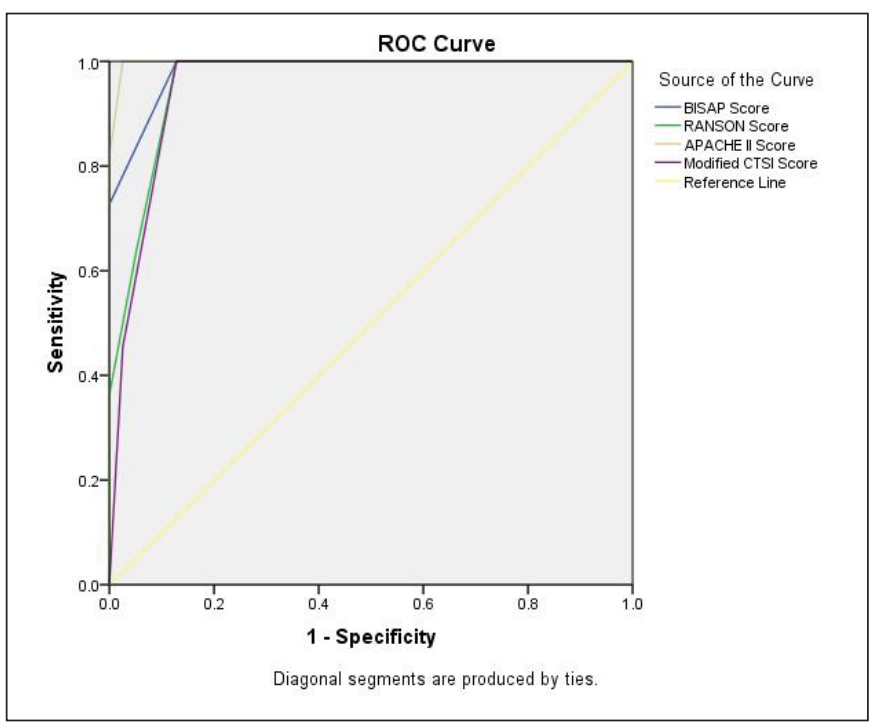

FIGURE 2. Comparison of various scoring systems in predicting outcome. severe forms of the disease have a mortality of up to $20 \%$. These high risk group of patients are likely to benefit from aggressive management like intravenous antibiotics, specific therapeutic procedures such as endoscopic sphincterotomy and provision of ICU facilities ${ }^{(17)}$. But ever since the introduction of different scoring systems there has been ongoing debate regarding which one to follow. So, this study was conducted to elucidate the reliability of these different scoring systems. The area under curve and accuracy had been highest for APACHE II in predicting severity, organ failure and death in patients of acute pancreatitis, with BISAP and Ranson scores closely following it. For predicting local complications modified CTSI was at par with APACHE II.

The differences in validity of these scoring systems are likely attributed to the parameters they are based upon. APACHE II being a composite scoring system with a wide range of variables often gives an insight into the ongoing pathophysiology and upholds accurate predictions. Ranson is also a widely used scoring system but it is a two step system, and can be obtained only after 48 hours of admission, unlike APACHE II and BISAP which can be obtained at any point of time. Although, a relatively simpler scoring system BISAP has comparable accuracy. In fact, BISAP score has $100 \%$

TABLE 4. Comparison of various scoring systems in predicting outcome.

\begin{tabular}{|c|c|c|c|c|c|c|c|c|c|c|}
\hline Scores & & Death & Survived & $P$-value & AUC & Sensitivity & Specificity & PPV & NPV & Accuracy \\
\hline \multirow{2}{*}{ BISAP } & $<2$ & 0 & $34(100)$ & $<.001$ & 0.983 & 100 & 87.18 & 68.75 & 100 & 100 \\
\hline & $\geq 2$ & $11(68.75)$ & $5(31.25)$ & & & & & & & \\
\hline \multirow{2}{*}{ RANSON } & $<3$ & $1(2.95)$ & $33(97.05)$ & $<.001$ & 0.960 & 90.9 & 84.61 & 62.5 & 97.05 & 86 \\
\hline & $\geq 3$ & $10(62.5)$ & $6(37.5)$ & & & & & & & \\
\hline \multirow{2}{*}{ Modified CTSI } & $\leq 4$ & $2(5.89)$ & $32(94.11)$ & $<.001$ & 0.952 & 81.82 & 82.05 & 56.25 & 94.11 & 82 \\
\hline & $>4$ & $9(56.25)$ & $7(44.75)$ & & & & & & & \\
\hline
\end{tabular}

AUC: area under the ROC curve; PPV: positive predicative values; NPV: negative predicative values; BISAP: Bedside Index of Severity in Acute Pancreatitis; APACHE: Acute Physiology And Chronic Health Evaluation.

TABLE 5. Different studies comparing validity of scores with severity of acute pancreatitis.

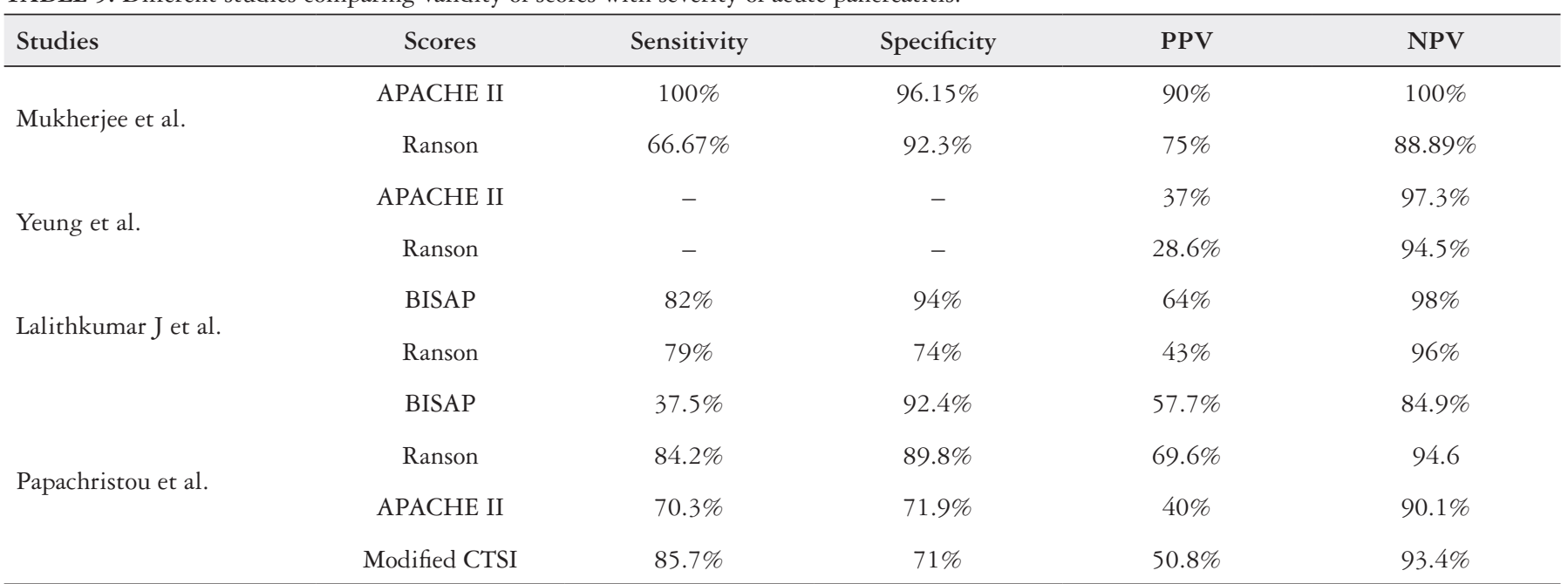

PPV: positive predicative values; NPV: negative predicative values; BISAP: Bedside Index of Severity in Acute Pancreatitis; APACHE: Acute Physiology And Chronic Health Evaluation. 
negative predictive value in evaluation of severity and mortality and $97 \%$ concerning organ failure. On the other hand, modified CTSI being a radiological parameter has limited systemic implications and thus turned out to be less accurate in predicting severity, organ failure and fatal outcomes in these patients.

In a study by Mukherjee $\mathrm{R}$ et al. ${ }^{(18)}$ regarding correlation of scores with severity of acute pancreatitis, sensitivity, specificity, PPV and NPV for APACHE II score had been 100\%, 96.15\%, 90\% and $100 \%$ respectively, in contrast to $66.67 \%, 92.30 \%, 75 \%$ and $88.89 \%$ for Ranson. Yeung et al. ${ }^{(19)}$ in their study, established PPV and NPV values for APACHE II and Ranson at 37\%, 97.3\%, 28.6\% and $94.5 \%$. Lalith kumar J et al. ${ }^{(20)}$, in their study compared BISAP and Ranson in terms of severity of pancreatitis with sensitivity $82 \%$ vs $79 \%$, specificity of $94 \%$ vs $74 \%$, PPV $64 \%$ vs $43 \%$, NPV $98 \%$ vs $96 \%$ and accuracy $93 \%$ vs $88 \%$. In a study by Papachristou et al. ${ }^{(21)}$, NPV for severity of acute pancreatitis had been $84.3 \%, 95.3 \%, 90.1 \%$ and $93.4 \%$ for BISAP, Ranson, APACHE II and modified CTSI respectively. Results of different studies are illustrated in TABLE 5. Despite the variability in these results it is well elicitable that APACHE II, BISAP and Ranson all have considerable negative predictive value regarding suspicion of organ failure, prediction of severity and evaluation of mortality risks. However, for local complications modified CTSI score is most reliable.

\section{CONCLUSION}

Although APACHE II yielded better results in predicting severity, organ failure and outcome, BISAP score also holds significant value in predicting them. It should be utilised in limited set up and with time constraint to take prompt decisions rather than waiting for investigations and calculating the APACHE II score. The accuracy of Ranson also closely follows APACHE II and BISAP. Modified CTSI did not perform well but nevertheless it is indispensable in view of local complications and subsequent surgical management as warranted by the complication.

\section{Ethics}

Ethics Committee Approval: approved by ethical committee of Pt B D Sharma University of Health Sciences Rohtak (Haryana), India.

\section{Authors' contribution}

Concept: Jain D. Surgical and medical practices: Jain D, Bhaduri G, Jain P. Design: Jain D, Bhaduri G. Data collection or processing: Bhaduri G, Jain P. Analysis or interpretation: Jain D, Bhaduri G, Jain P. Literature search: Bhaduri G, Jain P. Writing: Jain P, Bhaduri G. All authors have read the article and agree with the contents.

\section{Limitation}

As the study was conducted in the medicine ward, mostly the patients had alcoholic pancreatitis. So further larger studies are required to establish the validity of these scoring systems regarding other etiologies of acute pancreatitis, like gall stone and congenital anomalies.

\section{Orcid}

Deepak Jain. Orcid: 0000-0001-9476-3671.

Gourab Bhaduri. Orcid: 0000-0003-3825-5626.

Promil Jain. Orcid: 0000-0002-6390-7465.

Jain D, Bhaduri G, Jain P. Diferentes sistemas de pontuação na pancreatite alcoólica aguda: qual a seguir? Um dilema em curso. Arq Gastroenterol. 2019;56(3):280-5.

RESUMO - Contexto - A pancreatite aguda é uma desordem comum na prática médica. Nos últimos tempos, sua gestão mudou drasticamente com a maioria das decisões tomadas baseadas na gravidade da doença, como administração de antibióticos intravenosos, sucção negativa com o tubo de Ryle ou intervenções cirúrgicas como necrosectomia, etc. Há diferentes escores em uso para avaliar a gravidade da doença, mas a eficácia relativa manteve-se um assunto discutível. Objetivo - O presente estudo foi assim realizado para investigar a acurácia preditiva de diferentes sistemas de pontuação na pancreatite aguda. Métodos - Foram selecionados 50 pacientes com pancreatite aguda admitidos na enfermaria de medicina de Pt. B.D. Sharma PGIMS, Rohtak, Índia, e foram considerados para estudo após o cumprimento dos critérios de elegibilidade. Estes pacientes foram investigados na admissão e seguidos prospectivamente. A severidade da pancreatitie foi classificada para cada um destes pacientes pelo sistema de classificação Atlanta revisado. Os sistemas de pontuação comumente usados pertencentes à pancreatite aguda, ou seja, BISAP, Ranson, APACHE II e CTSI modificado foram calculados. Posteriormente, esses escores foram correlacionados com a severidade, presença de falência de órgãos, ocorrência de complicações locais e desfecho final dos pacientes. Resultados - Dos 50 pacientes, a ingestão crônica de álcool foi a etiologia em todos, exceto em um com pancreatite idiopática. A média de idade da população estudada foi de 42,6 $\pm 13,27$ anos. Destes pacientes, $32 \%$ apresentavam necrose pancreática, $40 \%$ apresentavam coleções peripancreáticas, $56 \%$ apresentavam pancreatite aguda leve, $24 \%$ apresentavam pancreatite aguda moderadamente grave, enquanto $20 \%$ apresentavam pancreatite aguda grave. O APACHE II teve maior precisão em prever a severidade, a falha do órgão e resultados fatais. No que diz respeito a esses parâmetros, os valores preditivos negativos do escore BISAP também foram consideráveis. A contagem modificada de CTSI foi exata em prever complicações locais, mas teve a exatidão limitada em outras predições. Conclusão - O APACHE II emergiu como o sistema de pontuação mais confiável seguido por BISAP e Ranson na gestão dos pacientes com pancreatite aguda. Mas em condicionantes do tempo e dos recursos, mesmo a Pontuação do BISAP com seus valores preditivos negativos significativos, serviu como uma ferramenta valiosa para avaliar e administrar esses pacientes.

DESCRITORES - Pancreatite alcoólica, classificação. Consumo de bebidas alcoólica. Adulto. Confiabilidade dos dados. 


\section{REFERENCES}

1. Brivet G, Emilie D, Galanaud P. Pro and anti-inflammatory cytokines during acute severe pancreatitis: an early and sustained response, although unpredictable of death. Parisian Study Group on Acute Pancreatitis. Crit Care Med. 1999;27: 749-55.

2. Whitcomb DC. Clinical practice: Acute pancreatitis. N Engl J Med. 2006;354:2142-50.

3. Isenmann R, Berger HG. Natural history of acute pancreatitis and the role of infection. Baillieres Best Pract Res Clin Gastroenterol. 1999;13:291-301.

4. Banks PA, Freeman ML. Practice guidelines in acute pancreatitis. Am J Gastroenterol. 2006;101:2379-400.

5. Waller A, Long B, Koyfman A, Gottlieb M. Acute Pancreatitis: Updates for Emergency Clinicians.J Emerg Med. 2018;55:769-79.

6. Negi N, Mokta J, Sharma B, Sharma R, Jhobta A, Bodh V, et al. Clinical Profil \& Outcome of Acute Pancreatitis: A Hospital Based Prospective Observational Study in Sub-Himalayan State. JAPI. 2018;66:16-21.

7. Ranson JH, Rifkind KM, Roses DF. Prognostic signs and the role of operative management of acute pancreatitis. Surg Gynecol Obstet. 1974;139:69-81.

8. Larvin M, McMahon MJ. APACHE II score for assessment and monitoring of acute pancreatitis. Lancet. 1989;2:201-5.

9. Balthazar EJ, Robinson DL, Megibow AJ. Acute pancreatitis: Value of CT in establishing prognosis. Radiology. 1990;174:331-6.

10. Wu BU, Johannes RS, Sun X, Tabak Y, Cornwell DL, Banks PA. The early prediction of mortality in acute pancreatitis: A large population based study. Gut. 2008;57:1698-703.

11. Foster BR, Jensen KK, Bakis G, Shaaban AM, Coakley FV. Revised Atlanta Classification for Acute Pancreatitis: A Pictorial Essay. Radio Graphics. 2016;36:675-87.
12. Talukdar R, Sharma M. Deka A, Teslima S, Goswami AD, Goswami A, et al. Utility of the "Harmless Acute Pancreatitis Score" in predicting a non-severe course of acute pancreatitis: A pilot study in an Indian cohort. Indian J Gastroenterol. 2014;33:316-21.

13. Dellinger EP, Forsmark CE, Layer P, Levy P, Maravi-Poma E, Petrov MS, et al. Determinant-Based Classification of Acute Pancreatitis Severity An International Multidisciplinary Consultation. Ann Surg. 2012;256:875-80.

14. Hamada T, Yasunga H, Nakai Y, Isayama H, Horiguchi H, Fushimi K, et al. Japanese severity score for acute pancreatitis well predicts in-hospital mortality: a nationwide survey of 17,901 cases. J Gastroenterol. 2013;48:1984-91.

15. Foster BR, Jensen KK, Bakis G, Shaaban AM, Coakley FV. Revised Atlanta Classification for Acute Pancreatitis: A Pictorial Essay. RadioGraphics. 2016;36:675-87.

16. Banks PA, Bollen TL, Dervenis C. Acute Pancreatitis Classification Working Group. Classification of acute pancreatitis-2012: revision of the Atlanta classification and definitions by international consensus. Gut. 2013;62:102-11.

17. The Pancreatology Working Group on Chinese Society of Gastroenterology of Chinese Medical Association. Draft criteria for diagnosis and treatment of acute pancreatitis in China. Mod Dig Interv. 2007;12:206-8.

18. Mukherjee R, Das P, Mukhopadhyay G, Bhowmik G. Is Ranson score still a valid prognostic tool in acute pancreatitis? Int J Sc Res. 2018;7:1-4.

19. Yeung YP, Lam BY, Yip AW. APACHE II system in prediction of severity of acute pancreatitis. Hepatobil Panc Int. 2006;5:294-9.

20. Lalithkumar J, Chitra T, Kodieswaran N. Comparative study between BISAP and Ranson's score in predicting severity of acute pancreatitis. Int Arc Intg Med. 2016;3:23-33.

21. Papachristou GI, Mudanna V, Yadav D, O'Connell M, Sanders MK, Slivka A, et al. Comparison of BISAP, Ranson's, APACHE-II, and CTSI Scores in predicting organ failure, complications, and mortality in acute pancreatitis. Am J Gastroent. 2010;105:435-41. 